\title{
Self-Compassion Of Bataknese Street Children
}

Rahma Yurliani, Indri Kemala, Liza Marini

Universitas Sumatera Utara, Fakultas Psikologi

\begin{abstract}
This research aimed to describe the self-compassion of Bataknese street children. Subjects involved in this study were 220 bataknese street children, selected by using incidental nonprobability sampling method. Teenagers who involved in this study are bataknese street children aged 12-18 years old. The data was collected through questionnaires about self-compassion. The self-compassion scale was developed based on self-compassion theory by Kristin Neff, composed of three components: self-kindness vs. self-judgment, common humanity vs. isolation, and mindfulness vs. over-identification. The results showed that self-compassion of subject belonging to the low category is $1 \%$, the moderate category is $37 \%$ and the high category is $62 \%$. If we look at self-compassion categorization based on its component then on self-kindness vs. self-judgment can be seen that low category is 3 , the medium is 63 , high is 154 . The medium category is $72.27 \%$, and the high category is $5.31 \%$. Whereas in the component of common humanity vs. isolation showed that it belongs to medium category in $10.6 \%$ and the high category is in $89.4 \%$. The components of mindfulness vs. over-identification indicate that .... In other words, it can be concluded that the largest group is in high self-compassion category.
\end{abstract}

Keywords: Self-compassion, Bataknese street children

\section{INTRODUCTION}

The phenomenon of street children has developed for a long time, but now is increasingly attracting the world's attention. Along with the increasing number of street children in various big cities in the world. Street children are individuals under the age of 18 who spend part or all of their time on the streets by engaging in activities to earn money or to sustain their lives (Shalahuddin, 2010).

Street children will face many challenges. Street children grew and developed with the background of street children's lives filled with poverty, persecution, and the loss of compassion. The most vulnerable street children to get that treatment are children who run away from home, which fall into the second category of street children, so-called children of the street (Surbakti, 1997).

Medan is a city that occupies the third position as the largest city in Indonesia which contributes to many problems. The problems that occur including various aspects of life. Starting from the vacuum of leaders due to corruption, bullying is increasingly prevalent, especially in the education sector, rampant cases, violent cases, child abuse, and neglect, to problems that have not been resolved and even increasing like street children. The existence of street children in the city of Medan has become a phenomenon that often raises various responses from the public, both positive and negative (Andriansyah, 2011).

There is no exact number of street children today. The Indonesian Commission for Child Protection called "Komisi Perlindungan Anak Indonesia (KPAI)" estimates that in 2006 there were around 150 thousand street children in Indonesia, with the largest concentration in Jakarta. However, based on the data obtained from Medan city's social service in 2008 the number of street children were equal to 675 people and in October 2009 the number of street children increased especially in Medan city to about 220 children or increased $1.8 \%$ compared to 2008 with only 150 street children (Dinas Sosial, 2008).

Based on the data obtained, Bataknese is a fairly large tribe in Medan city with an increase every year. Medan City is one of the most popular migration destination by Bataknese society. This of course affects the number of Bataknese street children. According to research conducted by Kartika Handayani (2009) on the identification of street children in the Medan city, states that most of her research subjects are Bataknese street children

Bataknese is a tribe that has much philosophy. One of them is Dalihan Natolu. Dalihan Natolu is the most important philosophy for Batak 
society.The harmony of this Batak local wisdom is still maintained in the middle of diversity. This philosophy is closely related to everyday life. Maintaining the harmony in the family relationship. For the Batak society, the degree of all citizens is the same; the differences are in the duty and the function of each citizen in need (Sihombing, 1986).

There is one proverb that reads: lapa-lapa pe di toru ni sobuon, malap das alap pe taho asal di hangoluan (an empty grain under husk, though it is hard as long as we live). Batak tribe loves life very much even though life is full of hardship. Optimism even though life is difficult but one day will get the joy as long as we committed to trying. (Agnes, 2013).

Self-compassion is a concept originated by Kristin Neff with the definition of affection related to the individual self as the object of attention when faced with negative events (Neff, 2003a). Neff (2009) mentions that self-compassion involves the need to manage personal health and well-being, and encourage initiatives to make changes in life. Lary et al. (2007) also state that individuals with self-compassion will accept the fact that they are deficient and imperfect, and are responsible for their actions. Self-compassion will lead individuals to good emotional competence, as described in Ramdhani's (2014) study which states that there is a major influence given by selfcompassion to emotional competence, as evidenced by the conformity with the moral natures, moral codes and moral regulations then one can behave adaptively and emotionally competent. This is in line with self-compassion that has a positive relationship with the function of a person's psychological adaptation (Neff, Rude \& Kirkpatrick, 2007).

Based on the background, the phenomenon of Bataknese street children in Medan when examined deeply is very interesting to be studied further. The principle of Bataknese that holds equal status for everyone influences their attitude of not feeling inferior to the condition they are in; they are expected to be more positive in facing life. This is inline with the concept of self-compassion which states that self-compassion involves the need to manage personal health, well-being and also encourage initiatives to make changes in life. Individuals with self-compassion will accept the fact that they are deficient and imperfect, and they are responsible for what they did. Therefore, researchers were interested to see the portrayal of self-compassion on Bataknese street children.

\section{RESEARCH METHODS}

This study uses a descriptive method that aims to describe the research subject. The sample used in this study is a sample that matches the characteristics of the population: street children, adolescents aged 12-18 years, Bataknese and domiciled in Medan. The sampling technique used in this research is incidental sampling technique. The data were collected using a Self-Compassion scale developed based on self-compassion theory by Kristin Neff (2015). The reliability of measuring tool is measured by using Cronbach Alpha technique assisted with the program of SPSS version 17.0 for Windows.

\section{RESULTS AND DISCUSSION}

The results showed that the selfcompassion of street children in Bataknese included in the low category was $1 \%$, the moderate category was $37 \%$, and the high category was $62 \%$. When viewed by its category based on its aspects, it can be seen that in self-kindness aspect, subject's self-compassion is mostly high (70\%), self judgment aspect is mostly moderate (50\%), Common humanity aspect is mostly high (65\%), the Isolation aspect is mostly high (48\%), the Mindfulness aspect is mostly high (90\%) and the over-identification aspect is mostly high (69\%).

\section{CONCLUSION AND RECOMMENDATION}

This study aims to determine selfcompassion on Bataknese street children. The study involved 220 Bataknesestreet children and are 12-18 years old who were selected using the incidental sampling method. The data was collected through questionnaires of selfcompassion scales developed based on selfcompassion theory by Kristin Neff (2015). The results showed that self-compassion on Bataknese street children is in the high category

\section{REFERENCES}

[1] Andriansyah .(2011). Anak Jalanan (Studi kasus atas persoalan sosial). https://www.scribd.com/doc/74394202/Fenome na-Anak-Jalanan-Di-Kota-Medan. Retrieved on tanggal 07 Oktober 2016. 
[2] Dinas Sosial Kota Medan. (2008). disosnaker.pemkomedan.go.id/. Retrieved on 05 November 2016.

[3] Hairani, dkk. 2006. The Dominant Factors of Children Becoming Street Children in Medan City. Journal of Development Studies, April, Volume 1, Number 2. Medan: Universitas Sumatera Utara.

[4] Handayani, Kartika. (2009). Identifikasi anak jalanan di Kota Medan. Essay. Medan: Universitas Sumatera Utara.

[5] Neff, K. D. (2003a). The development and validation of a scale to measure self-compassion. Self and Identity, 2,223-250.DOI: 10.1080/15298860390209035.

[6] Neff, K.D \& Vonk,R. (2009). Self-compassion versus global self esteem. two different ways of relating tp oneself. Journal of Personality 77-128.
[7] Neff, K. D. (2015).The Self-Compassion is a valid and theoretically coherent measure of selfcompassion. Mindfulness, 7 (1), 264-274. DOI: 10.1007/s12671-015-0479-3

[8] Shalahuddin, Odi. (2010). The Phenomenon of Medan Street Children; Problems and Solutions (A thematic study of the problems of Street Children, Between the demands and freedom of life). https://odishalahuddin.wordpress.com/2010/01/ 04/anak-jalanan-studi-kasus-atas-persoalansosial/. Retrieved on October 30, 2016.

[9] Sihombing, T.M. 1986. Batak Philosophy. Jakarta: Balai Pusaka.

[10] Suhartini, Tina (2009). Street Children Strategy for Surviving (Case: Street Children in Bogor City, West Java Province). Essay. Bogor: Institut Pertanian Bogor. 